Meta

Journal des traducteurs

Translators' Journal

\title{
The Monitor Model Revisited: Evidence from Process Research
}

\section{Sonja Tirkkonen-Condit}

Volume 50, numéro 2, avril 2005

Processus et cheminements en traduction et interprétation

Processes and Pathways in Translation and Interpretation

URI : https://id.erudit.org/iderudit/010990ar

DOI : https://doi.org/10.7202/010990ar

Aller au sommaire du numéro

Éditeur(s)

Les Presses de l'Université de Montréal

ISSN

0026-0452 (imprimé)

1492-1421 (numérique)

Découvrir la revue

Citer cet article

Tirkkonen-Condit, S. (2005). The Monitor Model Revisited: Evidence from Process Research. Meta, 50(2), 405-414. https://doi.org/10.7202/010990ar

\section{Résumé de l'article}

La recherche dans le domaine des processus de la traduction humaine montre que les chemins pour arriver à de bons résultats sont nombreux et que la conscience joue un rôle important dans l'identification des tendances et routines indésirables. Cette même recherche met également en relief que l'expertise dans le domaine qui nous intéresse exige des compétences de monitoring et de conscience de soi. Cette étude se concentre sur la modélisation du monitoring de la traduction basée sur des données empiriques. Il ressort clairement de nos études, que la tendance à la traduction littérale se retrouve dans les produits et processus aussi bien chez les apprenants que chez les experts. Le présent article plaide également pour d'autres recherches dans le domaine de la supposition d'un automaton de la traduction littérale ainsi que de ses mécanismes de monitoring. 


\title{
The Monitor Model Revisited: Evidence from Process Research
}

\author{
SONJA TIRKKONEN-CONDIT \\ University of Joensuu, Joensuu, Finland \\ sonja.tirkkonen-condit@joensuu.fi
}

\begin{abstract}
RÉSUMÉ
La recherche dans le domaine des processus de la traduction humaine montre que les chemins pour arriver à de bons résultats sont nombreux et que la conscience joue un rôle important dans l'identification des tendances et routines indésirables. Cette même recherche met également en relief que l'expertise dans le domaine qui nous intéresse exige des compétences de monitoring et de conscience de soi. Cette étude se concentre sur la modélisation du monitoring de la traduction basée sur des données empiriques. II ressort clairement de nos études, que la tendance à la traduction littérale se retrouve dans les produits et processus aussi bien chez les apprenants que chez les experts. Le présent article plaide également pour d'autres recherches dans le domaine de la supposition d'un automaton de la traduction littérale ainsi que de ses mécanismes de monitoring.
\end{abstract}

\section{ABSTRACT}

Research on human translation processes to date reveals that there are many routes to successful performance and that consciousness raising helps to identify undesirable tendencies and routines. Research on translation processes also shows that expertise calls for monitoring skills and self-awareness. This paper focuses on the monitor model of translation and reports on empirical evidence that supports the model. It shows that tendencies towards literal translation emerge in the products and processes of novices and experts alike. It also argues for further research into the hypothesized literal translation automaton and its monitoring mechanism.

\section{MOTS-CLÉS/KEYWORDS}

monitor model of translation, literal translation, expertise in translation, translation processes, translator training.

\section{The road to expertise is individual}

The days are gone when we believed that there are certain behavioural patterns that are necessary to achieve success in translation. We know by now that time factors, access to translation aids, leisured production, or professional routines do not account for success. For example, research on the use of time shows that spending much time for the preparatory stage, i.e. the stage before text generation, is not necessary for good quality (Hansen 2002b: 30). Second, translating without access to translation aids may improve translation quality (Livbjerg and Mees 1999), and spontaneous production may result in better quality than time-consuming and perfectionist procedures (Hansen 2002b: 15, 19). Also, reliance on professional routines may turn out an obstacle in tasks that require creativity and detachment from routines (Laukkanen 1993). 
One of the main findings from the research based on think aloud data, and from process research at large, is that it is dangerous to make sweeping generalizations about translation processes. There is wide individual variation in the processes of novices as well as those of skilled professionals. It has turned out, for example, that professional status does not necessarily guarantee high-quality performance, and conversely, that novices' performance may manifest features of expertise. This finding has important consequences for research that aims at identifying elements of expertise in translation processes. It means that studies of processes must be accompanied by an evaluation of product quality as well, if the aim is to pin down those process features that are found to be conducive to good quality.

Although there is great individual variation even among expert-level translators, there are still a number of shared features of expertise that emerge in several studies. An overview of these features is given in Tirkkonen-Condit (1996), and it is summarized in what follows. Here the term expertise is preferred to professionalism, as the focus is on processes that are observed to result in good performance. Expertise captures the idea that it is not professional status we are interested in but expert-level performance and the processes that account for it.

When the translation process is described in terms of the knowledge base utilized by the translator, expertise is characterized by a highlighted proportion of knowledge inferred from the source text. Whereas novices and non-experts tend to focus on lexical items and other micro-linguistic aspects, and to resort to text-external translation aids for information, experts tend to focus on the text itself and to maximize the amount of information to be gleaned from its semantic, pragmatic and inter-textual dimensions. Non-expert comprehension procedures tend to be locally oriented, while expert comprehension procedures tend to be globally oriented.

A similar local versus global distinction is to be found in the text generation procedures of non-experts and experts. A feature typical of experts' text generation is that some decisions about the entire target text are made at a relatively early stage of the process. Among such global decisions can be, for example, decisions about the overall style of the emerging target text. If a translator decides, for example, to use an authoritative style, then she will discard such translation variants that give an impression of compliance or pleasantness. Similarly, if a translator considers that the translation brief calls for stylistic or linguistic simulation of the source text, s/he might decide in favour of formulations that are not totally idiomatic. Stylistic decisions can be seen in think aloud protocols, for example, in the range of adjectives used by translators when evaluating potential translation variants or the text that has already been produced. The adjectives reflect the general impressions the translators are aiming at, as well as the impressions they wish to avoid. One translator, for example, expressed desirable qualities with such adjectives as natural, balanced, lucid, pleasant, elegant, simple, and undesirable qualities with expressions such as simplistic, mild, pedantic (Tirkkonen-Condit 1996: 254).

Experts have also been found to behave according to their global decisions and according to the principles they have adopted, while no similar compatibility between global aims and local decisions has been found in non-experts' performance. On the contrary there is often a conflict between voiced principles and action. Subjects representing non-expert performance may emphasize the importance of reference material or expert help, but in local decision-making situations end up just using a 
dictionary in spite of easy access to the internet, the telephone or the library. Such incompatibility between principles and local decisions is to be seen in the TAP excerpt from Laukkanen's (1997) study in example 1.

\section{Example 1}

kuinkas pitkä tää nyt olikaan (1) ei kovin pitkä (1) nyt tää pitäis ensin lukea mutta (.) kaikkien taiteen sääntöjen mukaan (.) mut mä en aio lukea tätä (laughs) (5.0) ku ei näit yleensä jaksa eikä ehdi nii (.) tai sitä lukee sitä mukaa ku tekee et kyl siinä sitte huomaa jos tulee jotain outoo

[let me see how long was this now (1) not very long (1) now then I should read this through first but (.) according to the rules of the game (.) but I'm not going to read it (laughs) (5) because you normally don't have the energy or the time so (.) or you just read it while doing it so you will see if something strange comes up]

Another feature of expertise is that decision-making effort is concentrated on those problem areas of the task which seem to have the greatest bearing on the outcome. Such crucial areas are, for example, titles and headings as well as pivotal terms, names or acronyms which get frequently repeated in the text. On the whole, experts have been found to invest decision-making effort strategically instead of wasting it on irrelevant details.

Focus on target text generation and monitoring its quality shows in the think aloud protocols of experts also in the distribution of evaluative expressions. It has been shown (Tirkkonen-Condit and Laukkanen 1996) that the proportion of target text evaluations (of all evaluative expressions identified in the think aloud protocols) grows with the level of expertise. Research with other methodologies supports the observation that expertise calls for monitoring skills (e.g. Sirén and Hakkarainen 2002; Hansen 2003).

Evidence from the research on professional translation also shows that experts are able to take an upper hand in relation to the source text. Séguinot (1989: 25-30), for example, reports on an observational study which shows that an expert translator improved the text in many respects with the result that the translation manifested greater precision and better coherence than the source text. In non-fictional translation this is often necessary, as source texts may be generated with little attention to the form of expression.

Although there is no one way to expert level performance, there is one topic, however, that emerges from expertise research and shows us where to focus research effort, when the aim is to glean knowledge on translation expertise. This factor is the ability to monitor one's own performance. An expert has self-awareness and monitoring skills, by virtue of which s/he also accumulates expertise with each task. As Hansen (2003: 26) points out, "creative individuals and experts possess the ability to give feedback to themselves. They have a clear goal and are in control of their actions. They feel and know at once if they have done something really well, or not so well."

I will now proceed to look at the traces we see in translation processes and products of the monitoring mechanism that controls unwanted literal rendering.

\section{Literal translation - a legitimate base in translation?}

The tendency to translate word by word shows in novices as well as experts, and in the data on processes as well as products. It looks as if literal translation is a default 
rendering procedure, which goes on until it is interrupted by a monitor that alerts about a problem in the outcome. The monitor's function is to trigger off conscious decision-making to solve the problem. Automation also affects the monitor, so that traces of its operation are not as frequently observable in the processes and products of experts as in those of novices and non-experts.

What I have sketched here resembles the monitor model of translation touched upon by Gideon Toury in his discussion on Vladimir Ivir's work (Toury 1995: 191192, 233). Toury's quotation from Ivir (1981: 58) is worth repeating here, as it nicely describes the phenomenon for which I am offering empirical evidence:

The translator begins his search for translation equivalence from formal correspondence, and it is only when the identical-meaning formal correspondent is either not available or not able to ensure equivalence that he resorts to formal correspondents with not-quite-identical meanings or to structural and semantic shifts which destroy formal correspondence altogether.

Ivir seems to assume that formal correspondence - or in my terms word by word or literal translation - is the default procedure resorted to as long as it satisfies the equivalence criterion. This is in line with the impression one gets from the empirical material discussed in this paper. Attempts to translate through formally corresponding material manifest themselves in key stroke logged data as false starts or misprints but in close analysis often turn out as attempts to translate literally, or with a formally corresponding item.

The empirical work that Toury (1995: 184-205) exemplifies as a method of research that could be used for testing the monitor model hypothesis is confined to analyses of translators' interim decisions. Interim decisions analysis utilizes the different versions and drafts of the translation that have been preserved and are available for analysis in addition to the published version. Toury (1995: 205) also appeals to us "to bring the results obtained by using this method to bear on the results obtained by using other research methods, e.g., thinking-aloud protocols - and vice versa." Thus my contribution can be seen as a proposal in favour of the monitor model and an invitation to judge whether the empirical observations discussed here serve as evidence for its validity.

There is empirical evidence that novices tend to approach a translation task as a series of lexical or phrasal problems that are to be solved in the order in which they appear in the text. In novices' performance, translation tends to proceed word by word, phrase by phrase, sentence by sentence. But there is evidence that literal rendering constitutes an element in translation processes at expert-level as well. Thus it can be seen as a challenge for research as well as training to try and identify the monitoring mechanism that operates in the expert's performance and prevents such literal renderings that are not linguistically acceptable or contextually appropriate as translation equivalents. Observing the manifestations of the monitoring mechanism in experts' as well as novices' processes may turn out educational in itself. In example 2 there is a quotation from an expert translator's think aloud protocol, which reveals the translator's search for a Finnish translation equivalent for artwork in the English source text. Artwork here refers to any graphic material, in addition to articles and photographs, which people might attach to the contributions they submit for publication to the editor of a magazine. (For a detailed report on the experiment see Tirkkonen-Condit 2002b: 104-106). 


\section{Example 2}

Hm (19) artwork hh (.) hetkinen (.) jos on kerran artikkelit ja valokuvat mainittu (7) piirrokset (.) muu kuvitus (21) tuskin kukaan taidetta lähettää (3) muu kuvitus kuulostaa:: aika yle- (1) yleiseltä (2) muusta aineistosta (.) muusta aineistosta

[hm (19) artwork hh (.) just a minute (.) since articles and photographs are mentioned (7) drawings (.) other illustrative material (21) I doubt if anyone would send art (3) other illustrative material sounds:: quite gene- (1) general (2) other material (.) other material]

The first item that appears in the think aloud as a potential translation equivalent for artwork is muu kuvitus (other illustrative material). It is followed by a pause of 21 seconds and an utterance that can be interpreted as a trace of the workings of the literal translation automaton. The word for word translation of artwork is taideteos (work of art), which is out of the question as a translation equivalent. At any rate the word taide (art) surfaces in the translator's think aloud (in the section printed in bold), albeit it is dismissed at once as a potential equivalent. The next item that appears in the translator's think aloud and eventually also in his target text is muu aineisto (other material). Here we see the monitor in operation: the translator verbalizes, perhaps as a potential translation variant, the item muu kuvitus, then pauses for 21 seconds and verbalizes something that can be interpreted as a trace of how the literal translation automaton and its monitor function when in operation: the word for word "equivalent" is generated, only to be dismissed immediately by the monitor.

The tendency to translate literally as a default procedure also emerged as a byproduct in a psycholinguistic experiment reported by Nili Mandelblit. In the experiment, bilinguals were asked to translate conventional idioms from French into English and vice versa, each subject translating into their mother tongue. The idioms were expressions relating to the passing of time, e.g. Cela fait bien longtemps que ... I It's been a long time since ...; Votre anniversaire approche / It's your birthday soon; Le moment est venu de ... I It's time to ...; Je trouve le temps long / Time is passing slowly. The aim was to find out whether the similarity or difference of the wording and/or the semantic domain exploited by each language affected the time spent on translating the idiom. With this experiment Mandelblit set out to test the "cognitive translation" hypothesis, i.e. that the idioms with a different cognitive mapping in the target language would be most difficult and thus take more time to translate. The hypothesis was very strongly supported by the results, as it turned out that it took about ten times longer to translate the idioms with a different mapping. The idioms with a similar wording in both languages were the "easiest" in that they took least time to translate.

But Mandelblit also reports on another result, which has relevance to the literal translation automaton hypothesis discussed here. In searching for an idiomatic translation equivalent for the expressions with a different mapping, "[I]t was noted that when translating DMC (different mapping condition) sentences, subjects tended to first suggest a word-to-word (and "same mapping") translation for the source sentence and only later propose the better translation. Though there was a high level of agreement as to the correct translation for each sentence, subjects were not as confident with the DMC translations as with the SMC (similar mapping condition) ones." (Mandelblit 1996: 493) When looking at this outcome from the perspective of our present discussion, we see the literal translation monitor at work here. When 
the subjects of Mandelblit's experiment are in the process of retrieving the correct idiomatic translation equivalent, their verbalization of the literal translation can be seen as an audition, in which a candidate is tested for appropriateness. After the audition, the monitor gives its verdict. The monitor needs time for this operation, and that is why the DMC sentences in the experiment take a longer time to translate.

Further evidence for the literal translation automaton and its monitor is found in the data collected by the keyboard logging software Translog. Below in examples 3 and 4 are two excerpts from a Translog file generated in an experiment administered by Kati Martikainen at Savonlinna School of Translation Studies in 2001. The subjects were asked to translate into Finnish 40 sentences retrieved from articles published in American journals during the presidential campaign of 2000. The aim of the experiment was to collect data on the translation of metaphoric expressions in context (Martikainen, forthcoming). The following excerpts of a Translog file relate to sentences Nos. 12 and 13 of the source text. In example 3 we will first look at sentence 12 and the log generated by one of the subjects in Martikainen's experiment. The highlighted sections in sentence 12 and its log illustrate the items affected by the literal translation automaton and its monitor in the instance of this translator.

\section{Example 3}

12. Which Bush is going to show up - the one who stayed on the high road with A. Richards or the one who was really low road with John McCain?

12. ** Kumpi $\bullet$ Bush $\bullet$ mahtaakaan nä $\otimes \bigotimes$ Xtulla esiin, $\bullet$ sekö joka * pysytteli $* * * * *$ tiukasti $\bullet$ A, $\otimes . \bullet$ Richardsin $\bullet$ linjoilla $\bullet$ vai $\bullet$ se, $\bullet$ joka $* * * \bullet \mathrm{ol} \otimes \otimes \otimes \bullet$ veti $\bullet$ oma $\bullet$ linjaansa $\bullet$ John $\bullet$ McCainin $* * * *$ jou $\otimes \otimes \otimes 凶 \bullet$ mukana.

The word for word Finnish equivalent for show up is näyttäytyä. As we can see, the first two letters nä of this word are typed, then deleted by backspacing and replaced by tulla esiin [come forth], which is more appropriate in the context. The word for word Finnish equivalent for was is oli. Again, the first two letters ol of this word are typed, then deleted and replaced by another phrase. In example 4 we will then look at sentence 13 and the log generated by the same subject as above.

\section{Example 4}

13. He has the ability to be aggressive without being nasty - something Gore, with his reputation for low blows, doesn't share.

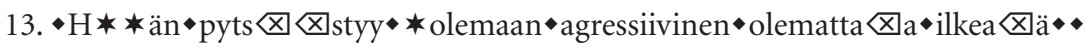
ominaisuus $* * \bullet \otimes \bullet$ joka $\bullet$ Gorelta $* \otimes \otimes \otimes \otimes \otimes \otimes \otimes 凶 * * * * * * * *$ puolestaan puuttuuu $\otimes \bullet$ halpamaisista $*$ tä $\otimes$ ölväisyistään $*$ tunnetulta Gorelta.

In the log for sentence 13 the highlighted section illustrates an instance in which the literal translation automaton generates something that can be seen as an attempt to imitate the word order in the English source text, in which the headword Gore is accompanied by a post-modification with his reputation for low blows. Since Finnish here calls for a pre-modification, the word Gorelta [from Gore] is deleted by backspacing and replaced by puolestaan puuttuu halpamaisista tölväisyistään tunnetulta Gorelta, in which the headword Gore is accompanied by a pre-modification.

The above phenomena can easily be distinguished from misprints or slips of the key by anyone who knows the target language and its repertoire of formal correspondence in relation to the source language. The phenomena we have witnessed above 
are very frequent in Translog files. As we have seen, the literal translation automaton operates on a lexical as well as syntactic level. Its monitor becomes more and more automatic at higher levels of expertise, however, so that its visible operation in terms of keyboard strokes diminishes. But even expert translators' keyboard loggings show such material that serves as evidence of the literal translation automaton and its monitor.

Keyboard-logged data provide valuable material for many kinds of analyses. Testing the monitor model hypothesis is just one example of how such data can be researched for the benefit of translation theory. Collecting and saving the products of translators' interim decisions by means of Translog is easy, if only we get translators and novices in translation interested in doing it.

Another source of evidence for the operation of the monitor model is to be found in simultaneous interpreting data. Olga Rouhe has recorded sessions of simultaneous interpreting from Finnish into Russian. She has transcribed the recordings and subjected the material to qualitative and quantitative analyses. Her aim is to find out whether syntactic asymmetry affects interpreting fluency. Her results to date show that instances of syntactic and lexical asymmetry between Finnish and Russian, such as is manifest, e.g., in the instance of genitive constructions and compound words, tends to cause repetition and repair in the interpreting speech. The genitive construction requires a shift of word order, while the compounds require an explication of the relation between the parts of the compound. In each case, an attempt at linearly identical or literal translation calls for monitoring, which in interpreting speech manifests itself as repetition and repair (Rouhe, forthcoming).

The product of simultaneous interpreting is a better representative of the process of translation than a typical product of written translation, as there is not much time to monitor the tentative outcome of the process. Thus a transcribed corpus of simultaneous interpreting is another valuable source of material for testing the monitor model against empirical data. The instances of repair in interpreting speech in Rouhe's corpus, for instance, deserve a close analysis from the point of view of the monitor model.

Further evidence for the operation of the literal translation automaton is to be found in our results concerning the so-called unique items. Unique items are such linguistic elements in the target language that are not triggered off as formal correspondents or literal translation equivalents by any elements in the source language texts. The results from our research on the Corpus of Translated Finnish, a comparable corpus of translated and original Finnish, show that the language specific or "unique" elements manifest significantly lower frequencies in translated than original Finnish. The elements that I have investigated include the clitic particles kin/ $k A A n$ and the verbs of sufficiency (see Tirkkonen-Condit 2004). The structures investigated by Sari Eskola are such "synthesizing" syntactic structures that do not have formally corresponding structures in English and in Russian, which were the source languages of the sub-corpora covered by Eskola's research (Eskola 2002, 2004).

The reason for the relative scarcity of the unique elements in translated language is that they are not generated by the literal translation automaton. They are not generated by the automaton, because there is no formally corresponding material in the source text to trigger them off, and secondly, because there are other lexical and syntactic vehicles to convey the semantic content expressed in the source texts. Thus 
the unique elements find their way to translations less frequently than to texts produced in the original.

The relative scarcity of unique material in translations can be taken as indirect evidence for the literal translation automaton in operation: it generates literal or formally corresponding linguistic material as long as the material thus produced is semantically and syntactically acceptable and satisfies the equivalence requirement. The unique elements tend to be ignored as the semantic content can be conveyed by the material generated by the literal translation automaton.

\section{How to exploit the current knowledge in translator training?}

Gyde Hansen (2002a) reports on the observation that there are great differences among novices in translation studies in awareness of the problems they come across in their translation assignments. On the other hand, awareness helps to monitor one's own performance. My own experience as a supervisor of M.A. theses shows that awareness of the student's own professional identity and competence grows, if the student has an opportunity to analyse his or her own translation process. Iina Toivanen translated a lengthy passage of a literary text to be reviewed by a potential publisher, while at the same time keeping files of her interim versions and making notes in a translator's diary. One of the main results of this project was the strengthening of the student's professional identity as a translator. For her the project as a whole was an empowering experience (Toivanen 2000). Tea Teinilä undertook a translation assignment which required extensive terminological research and consultation with the client. One of the main results from this project reported in Teinilä (2003) was that this assignment taught the author how to prioritize the requirements of the translation brief. It turned out, for instance, that much of the time-consuming terminological research was wasted, as those sections of the document that were most terminology intensive were omitted as irrelevant for the end user of the document.

In order to exploit the knowledge we have of translation processes in translation pedagogy, we will cater for individual choices, at the same time requiring each student to experiment with a wide variety of translation briefs. The translation briefs should range from fast performance tasks to long term assignments that call for independent and responsible action, extensive information search, risk-taking and experimentation, consultation with experts of all kinds, and responsibility for the final product. We should also teach students to observe and report on their performance critically. Collecting and analysing empirical data on one's own performance is facilitated by such devices as Translog, think aloud protocols, interim decisions analysis, and translation diaries. The same tools and methods that are now used in the research of translation processes can very well be used as training tools by novices in translation as part of their translation assignments. Think aloud and Translog could easily be integrated in virtually any kind of take-home assignment. These research tools might be adopted as pedagogical tools that enable the observation of one's own performance, which is a precondition for learning to monitor the performance in an expert manner. 


\section{NOTES}

1. Translog is a word processing software that saves all keyboard strokes while also registering their temporal progression. It was developed by Arnt Lykke Jakobsen and Lasse Schou. For a description of its operation, see Jakobsen (1999).

\section{REFERENCES}

EsкоLA, S. (2002): Syntetisoivat rakenteet käännössuomessa. Suomennetun kaunokirjallisuuden ominaispiirteiden tarkastelua korpusmenetelmällä. [Synthesizing structures in translated Finnish, A corpus-based analysis of the special features of Finnish literary translations.] University of Joensuu Publications in the Humanities 30, Joensuu, University of Joensuu.

Esкola, S. (2004): "Untypical Frequencies in Translated Language: A Corpus-Based Study on a Literary Corpus of Translated and Non-translated Finnish," in A. Mauranen and P. КUјАмӓкI (eds.), Universals in Translation. Do they exist?, Benjamins Translation Library 48, Amsterdam/Philadelphia, John Benjamins, p. 83-99.

Hansen, G. (2002a): “Selbstaufmerksamkein im Übersetzungsprozess,” In G. Hansen (ed.), Empirical Translation Studies. Process and Product, Copenhagen Studies in Language 27, Copenhagen, Samfundslitteratur, p. 9-27.

Hansen, G. (2002b): “Zeit und Qualität im Übersetzungsprozess,” In Gyde Hansen (ed.), Empirical Translation Studies. Process and Product, Copenhagen Studies in Language 27, Copenhagen, Samfukndslitteratur, p. 29-54.

Hansen, G. (2003): "Controlling the Process, Theoretical and Methodological Reflections on Research into Translation Processes," in Fabio Alves (ed.), Triangulating Translation, Benjamins Translation Library 45, Amsterdam/Philadelphia, John Benjamins, p. 25-42.

Ivir, V. (1981): “Formal Correspondence vs. Translation Equivalence Revisited," in Even-Zohar, Itamar and Toury, Gideon (eds.), Theory of Translation and Intercultural Relations, Tel Aviv, The Porter Institute for Poetics and Semiotics, Tel Aviv University. [= Poetics Today 2: 4.]

Jakobsen, A. (1999): "Logging Target Text Production with Translog," in Gyde Hansen (ed.), Probing the Process of Translation: Methods and Results, Copenhagen Studies in Language 24, Copenhagen: Samfundslitteratur, p. 9-20.

Laukkanen, J. (1993): Routine v. Non-routine Processes in Translation: A Think-Aloud Protocol Study, Unpublished M.A. thesis., Savonlinna School of Translation Studies, University of Joensuu.

Livbjerg, I. and I. M. Mees (1999): "A Study of the Use of Dictionaries in Danish-English Translation," In Gyde Hansen (ed.), Probing the Process of Translation: Methods and Results, Copenhagen Studies in Language 24. Copenhagen: Samfundslitteratur, p. 9-20.

Martikainen, K. (forthcoming): The Effect of Primary vs. Complex Distinction on Metaphor Translation, Doctoral dissertation, Savonlinna School of Translation Studies, University of Joensuu.

Mandelblit, N. (1996): "The Cognitive View of Metaphor and its Implications for Translation Theory," in Marcel Thelen, Barbara Lewandowska-Tomaszczy (eds.), Translation and Meaning, Part 3, Maastricht, Hoogeschool Maastricht, p. 483-495.

SÈguinot, C. (1989): “The Translation Process, an Experimental Study,” in C. SÉguinot (ed.), The Translation Process, Toronto, H.G. Publications, p. 21-53.

Roune, O. (forthcoming): The Effect of Syntactic Asymmetry on Fluency in Finnish - Russian Simultaneous Interpreting, Doctoral dissertation, Savonlinna School of Translation Studies, University of Joensuu.

Sirén, S. and K. Hakkarainen (2002): "Expertise in Translation, Across Languages and Cultures," A Multidisciplinary Journal for Translation and Interpreting Studies 3, 1, p. 71-82.

TeInilä, T. (2003): A Dip into the Translator's Mind, Self-observation of a Translation Process and Translation Competence, Unpublished M.A. thesis, Savonlinna School of Translation Studies, University of Joensuu. 
Tirkkonen-Condit, S. (1996): "What Is in the Black Box? Professionality in Translational Decisions in the Light of TAP Research," in A. Lauer, H. Gerzymisch-Arbogast, J. Haller and E. SteIner (eds.), Übersetzungswissenschaft im Umbruch. Festschrift für Wolfram Wilss zum 70. Geburtstag, Tübingen, Narr, p. 251-257.

Tirkkonen-Condit, S. (2002a): “Translationese - A Myth or an Empirical Fact? A Study into the Linguistic Identifiability of Translated Language," Target 14-2, p. 207-220.

Tirkkonen-Condit, S. (2002b): "Metaphoric Expressions in Translation Processes, Across Languages and Cultures," A Multidisciplinary Journal for Translation and Interpreting Studies 3-1, p. 101-116.

Tirkkonen-Condit, S. (2004): “Unique Items - Over - or Under-represented in Translated Language?," in A. Mauranen and P. Kujamäкi (eds.), Translation Universals, Do They Exist?, Benjamins Translation Library 48, Amsterdam/Philadelphia: John Benjamins, p. 177-184.

Tirkkonen-Condit, S. and J. Laukkanen (1996): "Evaluations - A Key to Understanding the Affective Dimension of Translational Decisions," Meta 41-1, Special issue on translation processes edited by Frank G. KöNigs, p. 45-59.

Toivanen, I. (2000): An Introspective Study of a Literary Translation Process and the Translator's Professional Self-image, Unpublished M.A. thesis. Savonlinna School of Translation Studies, University of Joensuu.

Toury, G. (1995): Descriptive Translation Studies and Beyond, Amsterdam/Philadelphia, John Benjamins. 